\title{
Sociolinguistics of Palestinian Arabic
}

\section{Introduction}

The aim of this lemma is partly to highlight various studies done over the years analyzing the high degree of linguistic variability in Palestinian Arabic. More than that, though, there is a sense that the linguistic situation, and indeed sociolinguistic complexity in Palestine more generally, are emblematic of the history of region and the speech community described in these studies. This is a community that has known, in the few decades since the commencement of scholarly sociolinguistic investigation, significant turmoil and devastation. It has been divided, partially exiled, and many of its members colonized and forced to learn other languages, further complicating their linguistic, political, and sociological statuses, to name but a few. Palestine is perhaps one of the prime examples of a site for which the study of the speech community and other types of social scientific research must continue hand in hand.

\section{Variationist Sociolinguistic Theory: An Overview}

At the core of contemporary sociolinguistic theory is the notion that language variation $(\rightarrow$ Variation) and language change ( $\rightarrow$ Mechanisms of Linguistic Change) are two natural and interrelated processes. Informed by seminal studies done in the West of both urban communities (e.g., by Labov in New York City and Philadelphia, Trudgill in Norwich, and Milroy and Milroy in Belfast) and rural communities (e.g., by Britain in East Anglia, and Wolfram in North Carolina), we have gained insight into similar instances of language variation and change in speech communities in the Arabic-speaking world (e.g., Haeri in Cairo, Holes in Bahrain, and Al-Wer in Amman). One of the advantages of this approach is that it contextualizes such concepts that have hitherto been deemed unique or quasi-unique to Arabic, such as diglossia ( $\rightarrow$ Diglossia) within the realm of the general study of language. While the Arabic situation, with its multitude of dialects alongside a somewhat stilted standard variety, may exhibit an extreme case of language variation, it is, in essence, not very different from other cases of standard languages and their corresponding vernaculars, such as Standard American English and African American Vernacular English in the United States, or Received Pronunciation and Cockney in England.

Another novelty in variationist sociolinguistics has to do with methodology. Sociolinguistic analyses are typically based on corpora of several dozen speakers from a given locale stratified by various social factors, some of which bear a more universal nature, such as age 
and sex/gender, and some which may be unique to the speech community at hand, such as ethnicity, religion, tribe, and linguistic or educational background. The purpose of collecting a methodically varied sample is to assure that it is as representative of the population as possible, such that it may account for the variation, which is assumed to inevitably be present in their speech. In most cases, the methodology includes a stage of quantitative analysis-some combination of statistical modeling techniques that helps the researcher determine which factors, linguistic, social, or both, are responsible for the variability in linguistic behavior.

It is important to keep in mind that language variation and language change are two separate processes, though they are not completely unrelated to each other. In order for a linguistic feature to change across an entire dialect, there must always have been a period during which that feature was unstable and in variation (for more about this, see Al-Wer 2013:244). For instance, if we assume that the urban Palestinian reflex of historical Arabic /q/, which in most cities (e.g., Jaffa, Jerusalem, and Haifa) is a glottal stop [2] (Horesh 2000, Levin 1994, Geva-Kleinberger 2004), developed directly from the voiceless uvular stop itself, we must assume that at some point in the past [q] and [?]-and indeed perhaps other variants, e.g., [k] or [k] -existed side by side, until ultimately the glottal stop became the sole phonetic representation reflecting the phoneme /q/. Such a case, where [q], [k], [?], and even the Bedouin-sounding [g], all still exist side by side, is evident in Amara et al.'s (1999) study of Bethlehem.

However, many other instances of variation never end up stabilizing and advancing to the level of language change. Occasionally we observe generation after generation of speakers using different linguistic features, including stylistic or other types of intra-speaker variation. We find such examples in phonology, such as the different phonetic realizations (described below in section 8) of the phoneme which is historically described as the voiced pharyngeal fricative $/ \Upsilon /$. In variationist sociolinguistics, variables are denoted in parentheses. This variable will later be referred to as ( () . It is also common to find unstable sociolinguistic variables in other domains of linguistic analysis, such as morphosyntax. An example of this in Palestinian Arabic is the fluctuation between synthetic and analytic expressions of possession. One may express possession synthetically using a clitic, as in (1) below:

(1) bēt-i.

Another option is to use an analytic construction, with a separate genitive exponent $(\rightarrow$ Analytic Genitive), as in (2) and (3):

(2) il-bēt taba'-i,

(3) il-bēt šèt-i.

The choice whether to use clitic pronouns as in (1) or the construct state ('idāfa) in general, 
or one of the two particles in (2) and (3) may depend on various factors. In fact, there are several hypotheses regarding the conditioning, and some have argued that the two kinds of possessive are simply in "free variation". A similar explanation has been given regarding the lexical variation between (2) and (3). One of the tenets of variationist theory is that "free variation" is never an adequate explanation. Horesh (2014) has begun investigating this very issue, with the intent to arrive at a conclusion using sociolinguistic theory and methodology.

\section{The Influence of Social Factors in the Study of Arabic}

Sociolinguistics, from its inception and early focus on English-speaking communities in the United States and Western Europe, has helped to expand the study of Arabic dialects outside of the realm of theoretical linguistics and dialectology. Key studies (Al-Wer 1991, 2007; Haeri 1996; Holes 1987) in Arabic sociolinguistics have laid the groundwork for the continued study of Arabic through sociolinguistic means. The work of Hachimi $(2007,2012)$ and Ismail (2009) are two primary examples of more recent developments in the study of language variation and change in Arabic-speaking communities. However, Arabic sociolinguistics is still an emerging area of research and although interest is on the rise, results remain generally limited to a collection of already well-documented areas.

By taking into account social qualities such as age, gender, social class, or dialect background in the study of Arabic, it has been possible for sociolinguists to begin to examine the influence of changing social structure, protracted political conflict, migration, and a wealth of other factors on language variation and change in the Arabic-speaking world. In addition to the benefits it offers in the context of Arabic studies, sociolinguistics as a general field of inquiry has been on the forefront of engaging with new methodologies and theoretical standpoints. Studies on Arabic which employ the theoretical assumptions put forth by variationist sociolinguists such as Labov or Eckert offer the chance to test these theories outside of the predominantly English-speaking communities from which they emerged.

In the case of Palestinian Arabic ( $\rightarrow$ Palestinian Arabic, $\rightarrow$ Jerusalem Arabic), sociolinguistic analysis has the capacity to add greatly to the scholarly understanding of this collection of dialects within the wider community of Eastern Arabic dialects. However, with the exception of recent works discussed below, sociolinguistic studies of Palestinian Arabic remain limited. Sociolinguistic analysis of dialect formation in Amman (Al-Wer 2007, see section 4 below) has shown that Palestinian Arabic, specifically the Nablus dialect, plays a critical role in the development of a koineized variety of Arabic in Amman. Research in this vein has also provided important data on dialect contact between Palestinian Arabic and Jordanian Arabic $(\rightarrow$ Jordanian Arabic (Amman)) in Amman. Additionally, Hennessey (2011) provides an initial examination of variation in the speech of Palestinian refugees in Lebanon. Notable in this instance is an attempt to utilize social-network analysis in the study of Arabic, an area which previously has not been thoroughly investigated. Sociolinguistic study of Palestinian Arabic 
carries with it not only the potential for significant contribution to sociolinguistic theory, but also to dialectology and theoretical linguistics through the examination of Arabic dialects that remain understudied and dialects that have undergone drastic demographic and social change in recent decades.

In the study of language variation and change in Palestinian Arabic, or Arabic generally, the work of Arabic sociolinguists to fit what can be considered 'standard' social categories (defining features of the speech community such as age, gender, social class, etc.) in Western studies on sociolinguistics into the mold of Arabic speaking communities has encouraged a reexamination and reconceptualization of what these social categories mean. Recently, age as a social category has been redefined in the sociolinguistic analysis of Palestinian Arabic (Cotter 2013, Horesh 2014). Whereas past studies on English-speaking communities in particular have divided age based on generational divisions (Labov 1966, Trudgill 1972), within research on Palestinian Arabic, age has been conceptualized in an emic framework that focuses on some shared experience of time (Eckert 1997). In this sense, age can be thought of as intimately tied to defining factors in the lives of the speakers or the collective memory of the community as a whole.

In the Palestinian case, the political, military, and demographic events of 1948, 1967, and the First/Second Palestinian Intifadas act as defining moments in community history. These events carry with them distinctive sets of life experiences for the individuals who were born before, during, or after their occurrences. In analytical terms, generational divisions have been demarcated based on historical events, which have effectively aided in developing generational divisions outside of those typical of other sociolinguistic studies. By redefining age categories in this way, studies on Palestinian Arabic have been able to perhaps better account for the uniqueness of the Palestinian community within the wider Arabic-speaking community of which they are a part.

\section{Sociolinguistic Overview of Palestinian Arabic}

As Britain $(2002,2009)$ has noted, the discussion on the varied dialects of a language is often compartmentalized into a focus on the issues of urban versus rural dialects and the degrees to which contact between them takes place. In the case of Arabic, it is typical to also differentiate between sedentary and Bedouin varieties. In a sense, the question is not whether contact takes place, but to what extent it does. In the same vein, languages generally, and dialects specifically, are continually evolving entities that do not exist in a vacuum but instead interact on micro and macro levels with the social world surrounding them. Palestinian Arabic represents a prime example of the larger phenomenon of language variation and change, and of dialect contact as a more localized occurrence.

Within the wider collection of dialects falling under the umbrella of Palestinian Arabic, it is possible to quite clearly denote all of the major divisions typically applied in the study of 
Arabic dialects: Sedentary-both urban and rural-and Bedouin. Cadora (1992) classifies and defines Arabic dialects according to this "ecolinguistic" taxonomy and succinctly describes the types of variation present, to varying degrees, within Palestinian as well as other Arabic dialects. Crucially, these classifications are not hard and fast rules which define dialects. Rather, they provide a set of criteria on which Arabic dialects can be viewed and discussed as a collective entity ( $\rightarrow$ Dialects: Classification). By utilizing this taxonomy, it has been possible to note instances of shift in the types of dialects spoken in major Palestinian centers. De Jong (2000), based on an analysis of the data collected by Bergsträsser (1915) and Salonen $(1979,1980)$, has hypothesized a shift in the dialect of Gaza City from a more typically urban Arabic dialect towards one that has adopted a number of Bedouin characteristics. In the same vein, by examining the work of Seeger (2009) on the dialects of the villages surrounding Ramallah, we note rural features, which contrast with urban linguistic forms now characteristic of the city dialect of Ramallah itself, despite its history as a typically rural community

Since the creation of the state of Israel, contact between these dialects of Arabic has intensified and been compartmentalized by forced migration and political conflict. These external factors are ones that have unquestionably altered geographical divisions between communities and created new and intimate sites of contact between different Palestinian communities. The refugee camp represents one specific example of this type of environment. In the past, contact between speakers of a sedentary dialect of Palestinian Arabic like that spoken in Jaffa and those of typical Bedouin dialects from the Naqab (or Negev) must have been considerably less intimate. However, for decades, what can be presumed as daily contact between these communities has been a reality of camp life. Šāți refugee camp in Gaza City presents one of numerous examples of spaces where communities of varied dialect backgrounds now live in the same delimited geographic area and are in daily intimate contact (see Al-Shareef 2002 for a further case study on Jabaliyya refugee camp, one of the eight official refugee camps in the Gaza Strip). The Palestinian refugee camps in Lebanon, Syria, and Jordan can be cited as additional sites of contact between different dialects of Palestinian Arabic.

The political events of 1948 and 1967 have not only altered geographic divisions and brought waves of forced migration, but have also changed social structure and traditional ways of life. To exemplify these realities, Palestinians from Northern Palestine, who were made refugees in 1948 and now live in the heart of Beirut's refugee camps, have seen drastic shifts in their way of life. These shifts have resulted in the communities being transformed from ones which could be considered primarily village based into ones which now exist in the heart of Lebanon's largest metropolitan city. How these transformations manifest themselves in linguistic terms is an area that remains understudied, although Hennessey (2011) has opened a door for the discussion.

Furthermore, while Blanc (1964) has shown quite clearly that religion has been a social factor which manifests itself in unique linguistic features in Arabic dialects, in the study of Arabic sociolinguistics today this remains another area where research is lacking. Despite 
having representatives from the three major monotheistic faiths, research on Palestinian Arabic has yet to sufficiently investigate what role religion may potentially play in language variation. However, Blanc (1953) did provide commentary on the distinctiveness of the speech of the Druze community in Palestine. General remarks on Palestinian Christian speech have also noted unique linguistic features within a specific religious community $(\rightarrow$ Jerusalem Arabic).

Still, it remains unproven that the linguistic differences noted in these Palestinian communities can sufficiently be tied to community religious affiliation, or if they are instead manifestations of the wide range of urban, rural, sedentary, and other classifications typical of Arabic-speaking communities. It is also entirely plausible that these differences are the result of other social factors, such as socio-economic status, that have not been fully explored in the Palestinian community. Religion in this instance could be viewed as a social factor that acts as a proxy variable for other factors in sociolinguistic analysis (Al-Wer 2002, 2013). In depth quantitative sociolinguistic analysis of these communities may bring with it the possibility to tease out these influences and add to the analysis of the variation that has been documented in them.

Patterns of migration by Bedouin communities both within and through the areas in which Palestinian Arabic is spoken can also be considered a factor which bears on the variation witnessed within the dialects. Although Bedouin migration patterns out of the Arabian Peninsula into the Naqab desert region and in/through Sinai remain understudied (Bailey 1985, Stewart 1991), it is logical to postulate that the migration of these communities and their contact with Palestinian dialects of Arabic could have linguistic ramifications. De Jong's (2000) hypothesis on the influence of Bedouin dialects on the dialect of Gaza City and the collection of Bedouin features noted in the scholarly texts provides initial evidence on the influence of neighboring dialects on that of Gaza City. In this sense, the migration of Bedouin communities in the area could be potentially tied to economic factors that drew these communities to Gaza City, as a major urban area, and influenced contact.

In contrast to the discussion on the influence of Bedouin migration on Palestinian dialects of Arabic, it is possible to note restrictions on Bedouin migration in the other areas of Palestine. Rosenhouse (1982) has noted instances of sedentarization of historically Bedouin communities in the north of historical Palestine after the creation of the state of Israel in 1948. As Rosenhouse observes, at least to some degree local sedentary dialects appeared to be having an effect on the speech of the Bedouin community under investigation. Follow up studies in these once nomadic but now sedentary communities could provide further evidence on the influence of migration (or a lack thereof) on language variation and change.

Although historical Bedouin migration patterns and more recent sedentarization trends in these communities are a crucial aspect of language variation in this context, this is not the only sense in which migration as a factor bears on Palestinian Arabic. It remains as yet unstudied, but forced migration and protracted conflict is a reality of life for the Palestinian community. As noted previously, the mass housing of Palestinians of varied dialect 
backgrounds in United Nations refugee camps for the past six decades comes as a direct result of these overt political forces. Studies on other communities, which have seen forced migrations (see again Moosmüller and Granser 2006; Kochetov 2006; Riehl 2010), have shown that this migration does have linguistic ramifications. With further study, it is plausible that these results could come to bear for the case of Palestinian Arabic as well.

\section{Palestinian Arabic and its Influence in Amman}

The formation of the dialect of Amman $(\rightarrow$ Jordanian Arabic (Amman)) represents perhaps the most extensively studied sociolinguistic case involving Palestinian Arabic. As Al-Wer (2007) has thoroughly documented, the Ammani dialect was formed as a result of contact between traditional Jordanian speakers, represented primarily by the dialect of Sult, just north of Amman, and Palestinians from Nablus, who migrated to the fledgling Jordanian capital. Al-Wer found that among the oldest generation, dialect background played an important role in determining linguistic realization for (q), with a general maintenance of the heritage variants respective to both groups. Notable exceptions in this respect were Palestinian men, who showed an initial intrusion of the traditional Jordanian [g] in their speech, as well as Jordanian women, who use the glottal [?] reflex in a small number of instances.

In the middle generation, Palestinian men and Jordanian women adopted these incoming variants to an even greater degree, while gender emerged as an important factor in linguistic realization and the importance of dialect background diminished. Within the youngest generation, Al-Wer notes that in addition to gender and ethnic background, context and interlocutor prove to be further mitigating factors in determining the realization of (q). In this generation, female speakers use the glottal [?] reflex of (q) consistently, while male speakers based their variable production on the gender and ethnic background of their interlocutors (Al-Wer 2007:64-67).

\section{Diaspora Populations}

As a result of the creation of the state of Israel and the forced expulsions of Palestinians which took place in 1948 and 1967, Palestinian Arabic has shifted from a geographically localized collection of Arabic dialects to one spread throughout the wider Middle East. In addition to being spoken throughout historical Palestine-today the West Bank, Gaza Strip, and Israel-Palestinian Arabic is spoken throughout Jordan, with an especially strong presence in Amman. Large Palestinian refugee populations throughout the Levant have also given Palestinian Arabic a strong footing in Lebanon, Syria, and Egypt, although in every case they represent a linguistic minority. Sociolinguistic work on Palestinians in Lebanon and Syria would be a fruitful area for future research as it could reflect the opinions that 
historians, political scientists, and human rights officials have expressed for some time: namely, it could offer a linguistic view of the precarious position of Palestinian refugees in these countries.

Outside of the Middle East, large Palestinian communities exist in Europe and the Americas (e.g., Dearborn, Michigan and Chicago, Illinois, as well as in Chile and the United Kingdom). Sociolinguistic research on these diaspora populations could contribute to the study of the acquisition of Arabic as an L1 or L2. Khamis-Dakwar et al. (2012) have provided related research on language processing in diglossic Arabic situations.

\section{7. (Socio)linguistic Outcomes of Language Contact}

In Palestine itself, Palestinian Arabic has been subject to contact with other languages, particularly Modern Hebrew, at least since 1880 (Henkin-Roitfarb 2011:61). In the area declared unilaterally as "Israel" in 1948, contact has intensified immensely from that year on. Palestinians who escaped the Nakba, the forced expulsion that occurred between 1947 and 1949, had become citizens of the new state and began formally learning Hebrew and interacting with Hebrew speakers on a daily basis. A number of cities whose population had formerly been predominantly Palestinian gradually became mixed cities, with majority Hebrew-speaking Jewish populations and minority Arabic-speaking Palestinian populations: Haifa, Acre, Lydd, Ramleh, and Jaffa. A sixth mixed city, Nazareth Illit, was later formed. It had originally been built on the outskirts of Palestinian Nazareth as a Jewish town, but its population today includes a sizeable Palestinian minority of about twenty percent, akin to the overall proportion of citizens of Israel who are ethnically Palestinian.

The linguistic effects of contact are multifold. As indicated elsewhere in this Encyclopedia ( $\rightarrow$ Language Contact, $\rightarrow$ Ivrit, $\rightarrow$ Ivrit Loanwords), as well as in the Encyclopedia of Hebrew Language and Linguistics (s.vv. Arabic, Hebrew Loanwords in: Modern Period), this contact has led, inter alia, to mutual lexical borrowings at various stages of contact between the two languages. It is safe to say, however, that most of the Arabic-to-Hebrew borrowings occurred prior to the solidification of Hebrew as the majority language in the portion of Palestine colonized in 1948. Hebrew-to-Arabic borrowings began mostly after 1948, and probably more so after 1966, when the martial law, to which most of the Palestinian citizens of Israel had hitherto been subjected, was lifted. Furthermore, the borrowings from Hebrew into Arabic are ongoing, and are accompanied by a related phenomenon, code-switching ( $\rightarrow$ Codeswitching; also see Hawker 2013, esp. Ch. 4).

The most important underlying difference between borrowings from Arabic into Hebrew and those in the opposite direction is that the majority of Palestinians who partake in the former practice (mostly from amongst the Palestinians who are citizens of Israel) acquire Hebrew to a degree of at least "secondary bilingualism" ( $\rightarrow$ Child Bilingualism), whereas their Hebrewspeaking counterparts typically do not gain proficiency in Arabic beyond individual words 
and phrases. The all-encompassing proficiency that many Palestinians share with native speakers of Hebrew has led to additional linguistic processes, which scholars are only recently beginning to unearth and explain using sociolinguistic methods. Henkin (2010) and Horesh (2014) enumerate several contact-induced changes in progress in Bedouin Palestinian and urban Palestinian (Jaffa) Arabic that may be classified as "structural borrowing", to use the terminology introduced by Thomason and Kaufman (1988). These include phonological lenition including glottalization, vocalization, and deletion of the voiced pharyngeal fricative; shortening of long vowels and simplification of geminates; morphological processes such as nativization of plurals for Hebrew loanwords and reanalysis of complex Hebrew singular loanwords as plurals; and morphosyntactic variation in the use of analytic forms of possession.

\section{Microvariation Examples from Palestinian Arabic}

Numerous examples of microvariation in these dialects have been noted by dialectologists, and more recent sociolinguistic research on Palestinian Arabic has tied this variation to a number of social factors. The feminine ending variable (ah), akin to the tā marbüța of Standard Arabic, is one such case. Variation in this morpheme has been well documented across Arabic dialects, particularly in the dialects of the Levant which conditionally raise the vowel constituting this morpheme barring a number of phonological constraints (Owens 2006, Al-Wer 2007, $\rightarrow$ Beirut Arabic, $\rightarrow$ Jerusalem Arabic, $\rightarrow$ Jordanian Arabic (Amman), $\rightarrow$ Palestinian Arabic). In the case of Palestinian Arabic, this has also been discussed in a number of dialects (see Cleveland 1967, de Jong 2000, Rosenhouse 1982, Salonen 1979, 1980, and Shawarbah 2011,2012) among which it is possible to note what could be considered a "full spectrum" of variation for this morpheme. In Bedouin Palestinian communities (ah) is typically realized as an unraised [a], although Shawarbah $(2011,2012)$ provides evidence of an exception, while it is raised in many of the sedentary Palestinian dialects to a vowel in the neighborhood of [e] and even to [i] in some northern dialects.

In Arabic sociolinguistics, generally, the feminine ending is an emerging variable that has received somewhat limited attention by scholars. Al-Wer (2007) has investigated (ah) in the speech of indigenous Jordanians and Palestinians in Amman. In addition, recent sociolinguistic research in Gaza City (Cotter 2013) has documented this type of variation in the Gaza Strip. Palestinian refugees originally from Jaffa, whose dialect traditionally realizes this morpheme with a raised [e] in all phonological environments except following back consonants, showed a generational decline in the use of the raised [e] variant in favor of [a]. Among the youngest generation of Jaffa-origin speakers in the study only sixteen percent of tokens were realized with the traditional Jaffa [e] for (ah), showing evidence of a change in progress towards the loss of this feature in casual speech. Table 1 (from Cotter 2013) provides a cross tabulation for (ah) divided by age and speaker dialect background to illustrate the current situation in Gaza City. 


\begin{tabular}{|l|l|l|l|l|l|l|l|l|l||}
\hline \multicolumn{9}{|l|}{ Speakers of Gaza City Origin } & \multicolumn{9}{l|}{ Speakers of Jaffa Origin } \\
\hline Age & {$[\mathrm{a}]$} & {$[\mathrm{e}]$} & $\%[\mathrm{e}]$ & Total & Age & {$[\mathrm{a}]$} & {$[\mathrm{e}]$} & $\%[\mathrm{e}]$ & Total \\
\hline $17-39$ & 248 & 12 & $5 \%$ & 260 & $17-39$ & 141 & 26 & $16 \%$ & 167 \\
\hline $40-64$ & 307 & 29 & $9 \%$ & 336 & $40-64$ & 103 & 40 & $28 \%$ & 143 \\
\hline $65+$ & 88 & 10 & $10 \%$ & 98 & $65+$ & 49 & 57 & $54 \%$ & 106 \\
\hline & & & & 694 & & & & & 416 \\
\hline
\end{tabular}

Table 1: Cross tabulation of (ah) in Gaza City

Drawing from this larger corpus of over 1,100 occurrences of the feminine ending, the examples provided below reflect the type of variability present in this community. In particular, of these examples, the only one which reflects raising of the feminine ending comes from an elderly Jaffa refugee. This category of speakers was one of the only groups within the data collected in Gaza City (Cotter 2013) that showed consistent and widespread evidence of raising. (Words containing the feminine ending are underlined).

(4) ana țufülti kānat hịlwa. kunit sākna fi manția.

'My childhood was nice. I was living in an area...'

(5) iw jāritna yahūdiyye iw jāritna masịhīyye wa llāhi, lamma kunna jāyinn min almadrase...

'And our neighbors (fem.) were Jewish and Christian, when we were returning from school...'

(6) aktar min 'ašrin sana min talāta iw sabìn.

'More than twenty years since 1973'.

(7) 'ala ġazza țalabu minha alma'lūba.

'...to Gaza they asked for it, the maqluba'.

(8) ma waddūnīs 'a lmadrasa, la, t'alammit wa llāhi arūḥ 'a lmadrasa.

'They didn't take me to school, no, I learned to go to school [on my own]'. 
In addition to (ah), the Arabic phoneme traditionally realized as a voiced pharyngeal fricative, $/ S /$, has been reported in various anecdotal instances to be weakened, particularly in the dialect areas where speakers are also proficient in Modern Hebrew. This in itself is not surprising, as Modern Hebrew has essentially lost the distinction between $/ \varsigma$ / and the glottal stop / $/$, both of which are often vocalized or pronounced as phonetic zeros: $\varnothing$. A number of sociolinguistic studies (Horesh 2014, Cotter and Horesh 2014) have shown that lenition of $/ \mathcal{S} /$ in Palestinian Arabic is not unique to speech communities within Palestine that are in close contact with Hebrew, but when comparing a community such as Jaffa, where daily contact between speakers of the two languages is rampant, to the Ramallah/Jerusalem and Gaza communities, whose contact with Hebrew speakers is low to nonexistent, the degrees of lenition in Jaffa are significantly higher than in either of the other two communities.

\begin{tabular}{|l|l|l|}
\hline \multicolumn{3}{|l|}{ Level of regular contact with Hebrew speakers $(\mathrm{p}<0.05)$} \\
\hline $\begin{array}{l}\text { Contact } \\
\text { level }(\mathbf{0}-2)\end{array}$ & Log-odds & Tokens \\
\hline 2 & 0.749 & 2060 \\
\hline 1 & 0.211 & 442 \\
\hline 0 & -0.961 & 667 \\
\hline $\mathbf{R}^{2}=\mathbf{0 . 2 1 2}$ & & \\
\hline
\end{tabular}

Table 2: Jaffa vs. West Bank

Table 2 (adapted from Horesh 2014) approximates the division between the two communities. Speakers coded with a contact level of 0 are more likely to have been from Ramallah or Jerusalem; 1 and 2 were given to speakers from Jaffa with varying degrees of contact with Hebrew speakers. The multivariate analysis computer program Rbrul (Johnson 2009) has indicated that level of contact with Hebrew speakers is one of the factor groups found to be significant in determining whether the variable ( $($ ) will be lenited. The results in table 2 show that speakers who have no contact with Hebrew have negative log-odds, meaning that their tendency towards weakening the pharyngeality of the $(\Upsilon)$ is lower than the speakers with a score of 1 or 2 , whose log-odds are positive, indicating a stronger proclivity for lenition. For clarification, the $p$ value $(<0.05)$ indicates that this result is statistically significant, while the $\mathrm{R}^{2}$ of 0.212 reflects that this statistical model accounts for roughly twenty-one percent of the variation present in the data.

\begin{tabular}{|l|l|l|}
\hline \multicolumn{3}{|l|}{ Speech community $(\mathrm{p}<0.000001)$} \\
\hline Community & Log-odds & Tokens \\
\hline Jaffa & 0.381 & 351 \\
\hline Gaza City & -0.381 & 358 \\
\hline
\end{tabular}




\section{$\mathrm{R}^{2=0.055}$}

\section{Table 3: Jaffa vs. Gaza City}

The data in table 3 (from Cotter and Horesh 2014) are even more striking, for several reasons. First, they compare a small, yet equal, number of speakers from each community ( $\mathrm{N}=7$ from Jaffa and Gaza City each). Secondly, all of the speakers, including those sampled in Gaza City, were of Jaffa origin. In other words, the speakers sampled in Gaza City were either Jaffa-born or offspring of Jaffa-born refugees, and have acquired, to some degree at least, the Jaffa dialect. Thirdly, the Gaza Strip is much more isolated than the West Bank, as it has been under a nearly hermetic military siege imposed by the Israeli government since 2006. Even beforehand, movement between the Gaza Strip and the rest of Palestine was heavily restricted by the Israeli occupation, thus inhibiting interactions between residents of Gaza and Israelis (as well as other Palestinians) effectively since the late 1980s. It is not surprising, then, that while Gaza City speakers do exhibit variation in their pronunciation of the variable ( $($ ), speakers from Jaffa proper are far more prone to be influenced by the lenition of this phoneme in Modern Hebrew and therefore lenite it in their native Arabic as well.

The data collected in Jaffa by Horesh (2014) exhibit variation in various linguistic domains: phonology, morphosyntax, and discourse. In the examples below, words that traditionally contain a pharyngeal fricative are underlined. Note that these examples are transcribed such that they reflect other variable phonological rules as well. Some of these include de-pharyngealization of the traditionally "emphatic" consonants; de-gemination of consonants that are historically doubled; and shortening of long vowels.

(9) kunna kullna n’ūl "ihna 'arab”.

'We all used to say "we're Arabs”".

(10) hāda kulo šway šway žara, bād etamāni w'arb'în.

'All this happened gradually, after [19]48'.

(11) ba.arafś bizabet lēš yāni bas hiy wislat ilmužtama' ilyafawi wisil la daraže nno batal yiàamin bi ttag̀yìr. yāni.

'I don't know exactly why, y'know, but the society in Jaffa has reached a stage in which it no longer believes in change, y'know'.

(12) hume bisä’idu yxal ilwade’ hēk.

'They assist in keeping the situation as it is'.

(13) hayy 'ažami hay 'akbar ḥayy. hāda hayy il'ažami. 
'This is "Ajami", it's the largest neighborhood. This is the neighborhood of "Ajami"'.

(14) amaliyan, amaliyan hāda insān, illi huwe illi bfaržik adeš yafa ḥazine.

'Practically, practically, this is a person who shows you how sad Jaffa is'.

As shown above, not all speakers of Palestinian Arabic are bilingual. At any rate, even among bilingual and multilingual speakers, not all sociolinguistic variables are tied to language contact. One of the most widely studied variables in Arabic dialects is the historical uvular stop (q) $(\rightarrow$ Qāf, esp. §3). To illustrate the significance of fine-grained studies of sociolinguistic variation in a phonological variable such as (q), consider Blanc's (1953) meticulous account of the various pronunciations of the phoneme /q/ among the Druze speakers of the Western Galilee and Northern Mt. Carmel regions of Northern Palestine (he did not yet use the "( )" notation later introduced by Labov for linguistic variables).

Blanc (1965:69) reports: "The pronunciation of the /q/ as a postvelar voiceless stop is, no less than that of the interdental spirants, a rule-of-thumb sign, in this area, for recognizing a Druze". He contrasts the [q] realization of /q/ with the glottal stop realization of the Christian and Muslim speakers of the region, but immediately follows with a list of exceptions. A notable exception he cites are the two extended Druze families in Kufur Yasif, a predominantly Christian village in the Lower Galilee, whose dialect he describes as a "marked urban" (1965:17) one. The Druze there, he says, are "linguistically undistinguishable from the rest of the village"; Druze speakers in five other villages are reported to "say [q]" (1965:69). Blanc's description continues, with anecdotes, field notes, quotes from members of the community, and citations of other researchers. This kind of qualitative commentary is actually not foreign to modern sociolinguistics, and is making a comeback with the surge of ethnographic studies of language, which are often augmented by a quantitative component (or vice versa).

Cotter (2013) has studied the (q) variable in the city of Gaza. In this speech community there exist two main variants. Indigenous residents of the city typically pronounce a voiced velar stop [g], and many speakers whose ancestral origin is from elsewhere in Palestine occasionally pronounce a glottal stop [?]. Yet the variation between the two is complex enough to have warranted an in-depth examination of the variable beyond a simple taxonomy of dialect origin. As in many sociolinguist studies, gender, for instance, has been found to play a significant role in shaping the linguistic outcome of variation. Examples from the data provided by Cotter $(2013,2015)$ are provided below to elucidate the type of variation that exists in the present dialect of Gaza City (words with a historic /q/ are underlined):

(15) ġazza zamān baga ahsan min ha lwagit.

'Gaza back in the day was better than nowadays'.

(16) sab'a iw tamanin tagriban, sab'a iw tamanin yitg்ayyar alhāl kullu fi gițà ġazza iw fi ḍ̣affa 
ilgarbiyya.

'...around 1987 the entire situtation in the Gaza Strip and the West Bank changed'. 'arīb ilxamsa iw'arba'īn wāhad mustašhad, tảrïban.

'...around [19]45 someone was martyred around then'.

(18) ihna ěš biullak 'abil ilhijra jīna hèn 'abil ilhijra bi arba'a jīna hèn.

'we, what can I tell you, before the migration we came here, four [years] before the migration we came here'.

(19) hamāas fi ḍ̣daffa iza bișìr intixabāt gawwiyya hāda xața.

'If there are elections in the West Bank and Hamas comes out strong, that's a mistake'.

\begin{tabular}{|}
\begin{tabular}{|l|l|l|}
\hline Speech community $(\mathrm{p}<0.000001)$ \\
\hline Community & Log-odds & Tokens \\
\hline Jaffa & 0.381 & 351 \\
\hline Gaza City & -0.381 & 358 \\
\hline
\end{tabular} \\
$\mathbf{R}^{\mathbf{2}=\mathbf{0 . 0 5 5}}$ \\
\hline
\end{tabular}

Table 4: Distribution of $(q)$ by gender \& dialect origin in Gaza City

Table 4 highlights the interaction among different social factors, in this case, age, gender, and dialect origin (or ancestry). Female speakers originating in Jaffa-itself a town with a [?]-pronouncing dialect-pronounce (q) as a glottal stop almost categorically. Note that women with no connection to Jaffa also pronounce [?] almost five times as frequently as their male counterparts. We must also look at age (which Cotter did), and note that there are more women in the sample who were actually born in Jaffa itself and were forcefully expelled to Gaza than who were born on Gaza, while the men in the sample were all born in Gaza to parents who were refugees from Jaffa. A thorough sociolinguistic study evaluates, both ahead of time at the design stage and in its eventuality, many such social factors, as well as internal linguistic factors that may be germane to the variability at hand. Quantitative tools are then used to narrow down the possibilities and occasionally bring to light not only the obvious factors, but also those which were not originally hypothesized to be salient. 
external and extra-linguistic factors, Berlin: Mouton de Gruyter, 2002, 63-79.

- "The Formation of the Dialect of Amman: From Chaos to Order", in: Catherine Miller, Enam Al-Wer, Dominique Caubet and Janet C. E. Watson, eds., Arabic in the City, New York: Routledge, 2007, 55-76.

- "Sociolinguistics", in: Jonathan Owens, ed., The Oxford Handbook of Arabic Linguistics. Oxford: Oxford University Press, 2013, 241-263.

Al-Wer, Enam and Bruno Herin, "The Lifecycle of Qaf in Jordan", Langage et société 138, 2011, 59-76.

Amara, Muhammad, Bernard Spolsky and Hannah Tushyeh, "Sociolinguistic Reflexes of Socio-political Patterns in Bethlehem: Preliminary Studies", in: Yasir Suleiman, ed., Language and Society in the Middle East and North Africa. London: Curzon Press, 1999, 58-80.

Bailey, Clinton, "Dating the Arrival of the Bedouin Tribes in Sinai and the Negev", Journal of the Economic and Social History of the Orient 28/1, 1985, $20-49$. Blanc, Haim, Studies in North Palestinian Arabic; Linguistic Inquiries among the Druzes of Western Galilee and Mt. Carmel, Jerusalem: Israel Oriental Society, 1953. - Communal Dialects in Baghdad, Cambridge, MA: Harvard University Press, 1964.

Bergsträsser, Gotthelf, Sprachatlas von Syrien und Palästina, Leipzig: Hinrichs, 1915.

Britain, David, "Space and Spatial Diffusion", in: Jack Chambers, Peter Trudgill, and Natalie Schilling-Estes, eds., The Handbook of Language Variation and Change, Oxford: Blackwell, 2002, 603-637.

- "'Big Bright Lights' Versus 'Green and Pleasant Land'?: The Unhelpful Dichotomy of 'Urban' Versus 'Rural' in Dialectology", in: Enam Al-Wer and Rudolf de Jong, eds., Arabic Dialectology, Leiden: Brill, 2009, 223-248.

Cadora, Frederic. J., Bedouin, Village, and Urban Arabic: An Ecolinguistic Study, Leiden: Brill, 1992.

Cleveland, Ray, "Notes on an Arabic Dialect of Southern Palestine", Bulletin of the American Schools of Oriental Research 185, 1967, 43-57.

Cotter, William. M., Dialect Contact and Change in Gaza City, M.A. Thesis, University of Essex, 2013.

- "(q) as a sociolinguistic variable in the Arabic of Gaza City", in: Youssef Haddad and Eric Potsdam, eds., Perspectives on Arabic Linguistics XXVIII, Amsterdam: John Benjamins, 2015.

Cotter, William and Uri Horesh, "Jaffa Palestinian Arabic: A Contemporary and Diasporic Sociolinguistic Analysis", paper presented at Arabic Linguistics Society 28, Gainesville: University of Florida, 2014.

De Jong, Rudolf., A Grammar of the Bedouin Dialects of the Northern Sinai Littoral: Bridging the Linguistic Gap between the Eastern and Western Arab World, Leiden: Brill, 2000.

Eckert, Penelope, "Age as a Sociolinguistic Variable", in: Florian Coulmas, ed., The Handbook of Sociolinguistics, Oxford: Blackwell, 1997, 151-167. Geva-Klenberger, Aharon, Die arabischen Stadtdialekte von Haifa in der ersten Hälfte des 20. Jahrhunderts, Wiesbaden: Harrassowitz Verlag, 2004. Hachimi, Atiqa, "Becoming Casablancan: Fessis in Casablanca as a case study", in: Catherine Miller, Enam Al-Wer, Dominique Caubet and Janet C. E. Watson, eds., Arabic in the City, New York: Routledge, 2007, 97-122.

- "The Urban and the Urbane: Identities, Language Ideologies, and Arabic Dialects in Morocco", Language in Society 41/3, 2012, 321-341.

Haeri, Niloofar, The Sociolinguistic Market of Cairo: Gender, Class, and Education, London: Kegan Paul International, 1996.

Hawker, Nancy, Palestinian-Israeli Contact and Linguistic Processes, New York: Routledge, 2013.

Henkin, Roni, Negev Arabic: Dialectal, Sociolinguistic and Stylistic Variation, Wiesbaden: Harrassowitz, 2010.

Henkin-Roitfarb, Roni, "Hebrew and Arabic in Asymmetric Contact in Israel", Lodz Papers in Pragmatics 7, 2011, 61-100.

Hennessey, Andrew, The Linguistic Integration of the Palestinian Refugees in Beirut: A Model for Analysis, M.A. Thesis, American University of Beirut, 2011.

Holes, Clive, Language Variation and Change in a Modernising Arab State, London: Kegan Paul International, 1987.

Horesh, Uri, "Toward a Phonemic and Phonetic Assessment of Jaffa Arabic: Is It a Typical Urban Palestinian Dialect?", in: Manwel Mifsud, ed., Proceedings of the Third International Conference of AIDA, Malta: Salesian, 2000, 15-20.

- Phonological Outcomes of Language Contact in the Palestinian Arabic Dialect ofJaffa, Ph.D. thesis, University of Essex, 2014.

Ismail, Hanadi "The Variable (h) in Damascus: Analysis of a Stable Variable", in: Catherine Miller, Enam Al-Wer, Dominique Caubet and Janet C. E. Watson, eds., Arabic in the City, Leiden: Brill, 2009, 249-272.

Johnson, Daniel. E., "Getting off the GoldVarb Standard: Introducing Rbrul for Mixed-Effects Variable Rule Analysis", Language and Linguistics Compass 3, 2009, 359-383.

Khamis-Dakwar, Reem, Karen Froud and Peter Gordon, "Acquiring Diglossia: Mutual Influences of Formal and Colloquial Arabic on Children's Grammaticality Judgments", Journal of Child Language 39, 2012, 1-29.

Kochetov, Alexei, "The Role of Social Factors in the Dynamics of Sound Change: A Case Study of a Russian Dialect", Language Variation and Change 18/1, 2006, 99-119.

Labov, William, The Social Stratification of English in New York City, Washington, D.C.: Center for Applied Linguistics, 1966.

Moosmüller, Sylvia and Theodor Granser, "The Spread of Standard Albanian: An Illustration Based on an Analysis of Vowels", Language Variation and Change 18/1, 2006, 121-140.

Owens, Jonathan, "A Linguistic History of Arabic", Oxford: Oxford University Press, 2006.Riehl, Claudia. M., "Norm and Variation in Minority Language

Settings", in: Alexandra N. Lenz and Albrecht Plewnia, eds., Grammar Between Norm and Variation, New York: Peter Lang International, 2010.

Rosenhouse, Judith, "An Analysis of Major Tendencies in the Development of the Bedouin Dialects of the North of Israel",

Bulletin of the School of Oriental and African Studies 1, 1982, 14-38.

Salonen, Erkki, Zum arabischen Dialekt von Gaza. Teil I, Helsinki: Finnish Oriental Society, 1979.

- Zum arabischen Dialekt von Gaza. Teil II, Helsinki: Suomalainen Tiedeakatemia, 1980.

Seeger, Ulrich, Der arabische Dialekt der Dörfer um Ramallah. Wiesbaden: Harrassowitz, 2009.

Shawarbah, Musa, "The 'Imāla in Some Bedouin Dialects in the Negev", Jerusalem Studies in Arabic and Islam 38, 2011, 123-144.

- A Grammar of Negev Arabic: Comparative Studies, Texts and Glossary in the Bedouin Dialect of the 'Azāzmih Tribe, Wiesbaden: Harrassowitz, 2012.

Stewart, Frank. H., "Notes on the Arrival of the Bedouin Tribes in Sinai" Journal of the Economic and Social History of the Orient 34/1, 1991, 97-110.

Thomason, Sarah. G. and Terrence Kaufman, Language Contact, Creolization and Genetic Linguistics, Berkeley: University of California Press, 1988.

Trudgill, Peter, "Sex, Covert Prestige and Linguistic Change", Language in Society 1/2, 1972, 179-195. 